\title{
Intertextual Dialogue in the British Postmodern Novels: On the basis of Peter Ackroyd's Novels
}

\author{
Yegane Abdullayeva ${ }^{1}$ \\ ${ }^{1}$ Department of Literature of Foreign Countries, Azerbaijan University of Languages, Baku, Azerbaijan \\ Correspondence: Yegane Abdullayeva, Department of Literature of Foreign Countries, Azerbaijan University \\ of Languages, Baku, Azerbaijan. E-mail: yeganeabdullayeva2013@mail.ru
}

Received: October 20, 2017 Accepted: November 19, 2017 Online Published: February 10, 2018

doi:10.5539/ijel.v8n3p239 URL: http://doi.org/10.5539/ijel.v8n3p239

\begin{abstract}
The peculiarities of intertextual dialogue in the postmodernist novel in Britain are investigated in the article. Literary-theoretical matters of intertextuality were clarified and commented on its reflection as a form of dialogue in literature. The intertextual dialogue's functions were analyzed on the postmodernist novel as "The house of Doctor Dee", "The Lambs of London", "The Casebook of Victor Frankenstein" by Peter Ackroyd, the British writer. The reminiscences, allusions, quotations, and aphorisms used in the novels in a fact form the skeleton of the works and is the means to show heroes' characteristic features. P. Ackroyd presenting intertextual dialogue with the parallel commentary in the development of events "settles" them in certain cultural paradigms. So the writer makes open the structure of the postmodernist novel and opens the way for many interpretations.
\end{abstract}

Keywords: postmodernism, intertextual dialogue, "the death of the author", novel, reminiscences, allusions, quotation, Peter Ackroyd

\section{Introduction}

Mikhail Bakhtin's dialogue conception as a universal general cultural category, Yuri Lotman's view of text as a culture, Roland Barthes' thoughts of quotation mentality or Julia Kristeva's presentation of text as quotation mosaic became the burning problems of the modern literary criticism of latest years observing in all spheres of humanitarian science. Intertextuality especially the appearance of intertextual dialogue in literary works is based on several facts. On one hand, intertextuality is the cultural event and text category, on the other hand, it settles with the study of self-peculiarities of the literary works written in the different literary-cultural system. The principal peculiarity of postmodernism is that it unites art systems, accepts their features, and simultaneously creates new tendentious, idea and genres in literature. The features of all the aesthetical systems are determined in postmodernism. West and East tradition, ancient and modern art thought, mass and elite literature posses the same rights in the postmodernist text.

First of all the conception of author-reader-literary work is changed in postmodernist literature unlike in classical literature. Especially, it shows itself in the changing dealing the role and function of an author. The author is not the person presenting his values, he doesn't teach or advice doesn't put the choice before the reader. As a rule, the author becomes the observer in postmodernist work. So if the author's aim is not to dictate his values to the reader, it means his hero also changes. It deals with it that heroes in postmodernist literature don't possess model behavior. The borders among values, rules, and bans disappear, fictional imagination and reality mixture. The constant meaning exchange cleans the differences between "own" and "other" words; sign, word, text become the potential participant in intertextual dialogue, the leading category of postmodernist novel. So, by means of intertextual dialogue reader realizes and understands life and history, the dialogue is formed between modern works and classical ones.

In postmodernist literature, the role of the reader is also changed, he drops out of passive position. Language play and intertextual dialogue in modern literary texts make demands intellectual efforts of the reader. The reader's adopting the text presents the act of combined activity and this process helps the reader to grasp the depth of text, to understand the dialogue among the texts existing before.

So, intertextual dialogue can be described and studied by author and reader. From reader's point of view to determine intertextual dialogue deals with the understanding of texts deeply and discovering ties with other texts. 
From author's point of view, intertextual dialogue helps to contact the reader, to create his own text, to form systematic relationships among the other writers' works in his personal literary activity.

Intertextuality being a specific dialogue between texts is the relation with elements of the texts written nowadays and before. It may be observed in the lexical, semantically, structural and meaning spheres. Intertextuality is the tie with other text, dialogical relation providing meaning changes of texts. That's why intertextual dialogue means mutual relation of the texts within the same literary work under the principle of "parts create the whole".

Intertextual dialogue can be shown in different forms. They often fulfill certain functions as reminiscence, allusion, quotation, aphorisms: to open inter peculiarities of the hero of the work; to determine public and social status; to describe historical events; to emphasize figuratively utters in characters' speech; to find out moral features of hero and so on.

The object of the article is intertextual dialogue and its appearance forms in British postmodernist novel. For its nature and special peculiarities postmodernist novel as a genre is intertextual. It deals with the fact that the aesthetics of postmodernist novel accepts the making dialogues with the texts written in the past. The main aim of the article is to determine intertextual dialogue with the texts written in different literary systems of British novel and to find out its appearance in Peter Ackroyd's postmodernist novels:

- To clarify literary-theoretical matters of intertextuality;

- To determine the notion of intertextual dialogue within the frame of article theme;

- To define the special peculiarities of reminiscence, allusion, quotation, aphorisms, historical retrospection that create intertextual dialogue;

- To investigate the appearance features of intertextual dialogue in British writer Peter Ackroyd's novels;

- To find out the specific character of the postmodernist novel in Peter Ackroyd's literary activity.

\section{Ackroyd's Creativity in Literary Criticism}

The writer of Great Britain Peter Ackroyd's novels consists of the mixture of some literary genres. His novels are the synthesis, combination of historical, biographical, detective, memorial, scientifically fantastic genres. The writer forming the combination of genres and methods presents the cultural traditions in the unity of past and modern times. As a rule, P. Ackroyd's creative activity is dealt with the researching of English literary traditions and commenting on the national cultural context. The literary criticism studying his creative activity in different directions presents P. Ackroyd as a representative of postmodernist literature. J. Gibson, J.Wolfreys in "Peter Ackroyd: The Ludic and Labyrinthine Text", Ukko Hnninen in "Rewriting Literary History: Peter Ackroyd and Intertextuality"(12), Susana Onega in "Metafiction and Myth in the Novels of Peter Ackroyd" (15), Brian Finney in "Peter Ackroyd, Postmodernist Play and Chatterton" (9) investigates the writer's novels as the most successful postmodernist text.

Actually, P. Ackroyd describes national-cultural values, English traditions in characters of independent personage, manage to make dialogue between past and present in the creative space built by himself. Just this creative approach could make P. Ackroyd's novels important and interesting in the XXI century literary process.

J. Gibson, J.Wolfreys determine Peter Ackroyd as a representative of English postmodernist literature in the research work "Peter Ackroyd: The Ludic and Labyrinthine Text". They investigate the novels "Chatterton", "Hawksmoor" as a modern British postmodernist text of the writer using intertextual play method of the postmodernist novel, present them in the mutual relationship of past and present times or "the melting" of the past within present.

The Finnish literary critic Ukko Hnninen investigates the writer's creative activity due to the aesthetical principles of postmodernism and determine the literary methods as deconstruction, intertextuality and irony of the novels in the research work "Rewriting Literary History: Peter Ackroyd and Intertextuality". The researcher divides the novels "The Last Testament of Oscar Wilde", "Chatterton", "Dan Leno and the Lime house Golem" into the parts as "Intertextuality-plagiarism or true poetry", "Parody and the deconstruction of history", "Reconstruction of the literary canon" and approaches each novel through the postmodernist principles. Due to Ukko Hnninen P.Ackroyd's creative activity belongs to "the culture of discourse".

The Spanish researcher Susana Onega investigates the writer's novels "The Great Fire of London", "The Last Testament of Oscar Wilde", "Hawksmoor", "Milton in America", "Chatterton", "First Light" as a metatext, emphasises the use of metatext as a parody in the research work "Metafiction and Myth in the Novels of Peter Ackroyd". Due to the reseacher's view P. Ackroyd explains the past through the modern point of view reknowing it using the metatexts. 
In our article P. Ackroyd's novels are studied on the stage of intertextual dialogue and investigated due to structure and poetics of postmodernist text. P. Ackroyd's novels are studied in the form of dialogue between past and present, tradition and modernity and are regarded for. P. Ackroyd's creative activity based on postmodernist paradigms is emphasized to have the role of the bridge between the cultures of modern British and British of old days.

\section{Intertextuality as a Cultural Interaction Mechanism}

Every narrative always demands interpretation (both by the author and by the recipient), and that's why a narrative not only introduces a reality, but also creates it somehow in the imagination of the person, and produces it; namely the narrative "creates reality", but at the same time affirms the fact of its non-dependence on the reality of the physical world. Putting this in other words, we can say that the more a narrative discovers the world, the more it hides it or distorts it. This instant demonstrates a special function of narrative-narrative knowledge that manifests itself.

The concept of Intertextuality as a characteristic of post-modernist philosophy affirming the existence of a separately taken text as intertext, always including all the other texts into the structure in all levels, was put forth by the French poststructuralist Rolan Barthes in the XX century and found its solution in the theoretical viewpoints of poststructuralist of Bulgarian origin Julia Kristeva. The principle of Exocamera, determined by Roland Barthes is the practical analog of this, and according to this principle, each text to a certain degree is the reflection and echo of all other texts. So, in postmodern aesthetics the world is taken as a gigantic text, having no completion: each of the cells has been built upon the ground of the information given before; namely, it is possible to find out new details only by the principle of the Kaleidoscope. An unexpected combination of already uttered words forms a new word. According to Roland Barthes, "any text" is the echo of another text.

As important characteristic of Postmodernist discourse, is the principle of quotation, stating the possibility of building up a text on the basis of quotations taken from other works, including multiperspectivism, denoting the same degree of different views linked with a certain object.

It is possible to see that the enumerated postulates of postmodernism reflect the features of the field of unconsciousness and indicate the free combinability of signs among them. The principles of the impossibility of choosing and collage, for example, obligatorily free combinations of fragments of narratives, but unbelief to eclecticism and metanarrative substantiates the freedom of such signs. The principles of quoting and multiperspectivism, conditioning the reality of unconsciousness also are linked with free combinations of the fragments.

This feature of unconsciousness can be studied as the basis of intertextuality and exocamera, being the main principles of a postmodernism of continuity, indicating existence as all possible chances of the continuum, not fitting into any of them.

Other important principles of postmodernist philosophy do not reflect the chaotic and eclectic character of the structure of this philosophy but reflect its extreme impersonal character. Among these principles, before everything, the postulate of "the death of the author" (Roland Barthes) (7) can be indicated. Fitting to this postulate the author of the work is interpreted not as a concrete person, but he/she is interpreted as a certain place, and from this place, the richness of culture can be projected in the mentioned text. Another postulate of this type is "the death of subject" (Michel Foucault) $(4 ; 11)$ according to which not only the author loses the initial signs of conditions of real existence, but also they are lost by the reader. They are looked upon as the endless desert of imagination, or as one cell of culture. Another postulate known as "the vanishing of character in the novel" (Christine Brooke-Rose) (17) shows itself in the vanishing away of the character of the personage, which is considered as the focus of traditional danger.

The enumerated principles of postmodernist philosophy, we think, are linked with important principles of neutrality, related to the subject-object oppositions in the establishment of the field of unconsciousness and to the absence of exact counters of object and subject. These thoughts sound in harmony with one point of the considerations of Jean Baudrillard, who in his turn explains this principle of postmodernism (the death of the author) by the "theory of unconsciousness". Dealing with the "theory of unconsciousness" Jean Baudrillard affirms that "he points to endlessly lost object and always slipping away from the subject into the place of positive object and subject of consciousness"(6).

So, it is possible to see that postmodernism as an aesthetic phenomenon is the theoretical reflection of the field of unconsciousness and its main features are determined by the principles of the self-establishment of this sphere. Thus, intertextuality in XX century literature, affirming the existence of each separately-taken text as an intertext, 
always including all the other texts into its structure in different levels among the characteristics of postmodernist philosophy, can be turned to the principle of writing by writers, and the British postmodernist novel widely used this method.

Mikhail Bakhtin's creativity, influencing the aesthetic thought history of the XX century, we may say, was linked with literary events taking place in this century to a certain degree. M.Bakhtin's "dialogue conception influenced on the mode of thinking of thinkers such as Buber, Levinas" $(16 ; 48)$ showed its impact in the literary-theoretical creativity of R. Barthes and J. Kristeva. The thinkers' idea of "macrodialogue"-intertextual dialogue and "microdialogue"- the conception of dialogue of language forms of one literary piece with another one involved modern literary study; especially it involved the scope of problems of structuralism, postsculturalism, and postmodernism. J. Kristeva, who brought the conception of intertextuality into literary studies (13) expressed the changed version of M.Bakhtin's theory of "microdialogue" (5) the linking of one text with another one. The theory, put forth by J. Kristeva, first of all, was used by poststructuralists as they refused the "macro dialogue" theory, demanding the idea-contents interpretation of a work and accepting the theory of "micro dialogue" in studying the linguistic analysis of the text as a basis. Intertextuality, involving all the text, being different from "macro dialogue," considered the text as a whole as a dialogical one. R. Barthes, J. Lacan, M. Foucault, J. Derrida basing on the conception of J.Kristeva, declared that any text, as a part of the cultural fund of mankind, named them as the pretexts or intertexts of the texts to be created further on.

Intertextual reading of the text as a determination of the dialogue between the text and intertext, creates the ground for contextuality, discovering different new meanings, as new meanings are created in the concrete context in the form of intertext. So, intertexts formed in new contexts are used for other cases and for other ideas. Jonathan Swift's novel "Gulliver's Travels" consists of satiric and ironic allusions, but the hero of the work of Daniel Defoe's "Robinson Crusoe" is a parody of Robinson Crusoe and utopias. The novel of James Joyce "Ulysses" is a comparative parody of the epic poem of "Odyssey" written by Homer, while the plot of the novel "Joseph and His Brothers" written by Thomas Mann is the unchanged conception of the Bible legend, an intertextual text of covert meaning.

\section{Intertextuality as an Intergenerational Dialogue}

The XX century English Novel, especially creative activities of Peter Ackroyd, Angela Carter, Julian Barnes, Graham Swift, and Antonia Byatt, must be considered as the brightest examples of creators of intertextual texts. P. Ackroyd's novels "The Great Fire of London", "The Last Testament of Oscar Wilde" "The Lambs of London"; A. Carter's "Nights at the Circus", "Black Venus"; J. Barnes's "Flaubert's Parrot", "A History of the World in 10 $1 / 2$ Chapters"; A.Byatt's "Angels and Insects", and other novels of such kind are text specimens, determining the architexhtuality and metatextuality from the view of studying the intertextual correlations among texts, and from the view of study of literary peculiarities of intertextuality.

Peter Ackroyd's novel "The Lambs of London" from this viewpoint is especially of more interest. From the heroes of the novel "The Lambs of London," Charles and Mary's surname being "lamb", meaning little (newly-born) sheep, this the novel can be conceived of as "Newly-born sheep of London" as well.

However, in the Russian translation of this literary work it has been titled as "Londonskiye sochiniteli" (writers of London), and with the view of keeping the literary spirit of the literary piece, such a translation is more adequate. The work was written by the master of short studies based on Homer and Shakespeare's creativity, XIX century English Poet, playwright and literary critic Charles Lamb and his sister Mary, deals with the life of William Ireland who has been alleged to have given Shakespeare's discovered manuscripts in his own name. Besides this, a plot dealing with fragments of the lives of literary critics Thomas De Quincey and Richard Brinsley Sheridan attached to the novel exhibits it as a postmodernist work of literature. Epigraphs and quotations cited from English and world literature, reveal its intertextual correlations, but the "walks" on the work reveal its contextuality.

William Ireland's discovery of manuscripts of Shakespeare's testaments lost plays, and the tragedies "King Lear" and "Hamlet" establishes the plot of the literary work. Ireland's report with his considerations on the creative activity of Shakespeare awakes the feelings of envy in Charles Lamb, but very soon he is exposed and is forced to admit that the manuscripts which he exhibited as belongings to Shakespeare were his own writings. This conflict taking place in the work connects him with intertextual, architextual and metatextual ties with the works of other writers, but the expression of fragmentality unites different plots in one plot. For the connoisseur of postmodernist novels, in P. Ackroyd the world is a somewhat big text and one must never keep away from that which has been said; without looking to the works created before, it is impossible to create something new. From this point of view the hero of the work, being Ireland "privatizes" the past, writes by the name of Shakespeare, 
and "finds" new manuscripts. The novel called "The Lambs of London" is a text, kneaded with known and hidden quotations, reminiscences, allusions, and paraphrases from English literature and Bible motifs. One of the heroes of the novel, Charles Lamb, cites from the real Charles Lamb, based on his essays.

At one point in the work Charles Lamb reminds the reader of the English novel "Tristram Shandy" and the creative activity of the author of "Sentimental journey through France and Italy," Lawrence Sterne, and wants to know about resemblances between his creative activities with the creative activity of Charles Lamb, if there are any. He hints at the essay "The Praise of Chimney-Sweepers" included into "Elins Essays" which belongs to Charles Lamb in the history of English literature: "According to Matthew Law, that comment a "powerful outburst" was considered, and since Charles had become a regular contributor to the weekly. At that time he was writing an article praising chimney sweeps. I had read Sterne to see if your favorite novelist had ever addressed the issue" (2).

As is obviously seen from the extract of this text, historical retrospection creating the necessity of coordination not with the plot of the work, but with intertextual coordination has been realized by [the emphasis of legacy among the nations.]-unclear-what nations?

However, in another place in the work, the quotation cited from the Ivth act of scene Iof the Shakespeare's tragedy "Macbeth" changes the load of the meaning of the work and creates intertextual coordination: "He thought it looked like a witch, a nocturnal shrew. They said he was doomed". He ran and turned into a shadowy corner. His rush was such that collided with someone" (2).

When we sound the thoughts of the Ancient poet of Rome, Horace, the author of "Epodes" and "Odes " on beauty and link it with Shakespeare's tragedy "Macbeth", we load another meaning on the dialogue between the heroes:

"-No, I do not mean here and now, but relaxed months of summer, the heat wave. As Horace says, the days of wine and roses.

-You just speak. Drink wine, we eat roses and aspire scented breath of Arabia" (2).

On the Lady Macbeth's expression from act V scene I of the "Macbeth" tragedy, "Here's the smell of the blood still. All the perfumes of Arabia will not sweeten this little hand" $(14 ; 990)$ is an allusion to the expression. The fact that P. Ackroyd sounds the thought of the poet on beauty together with the expression of Lady Macbeth, already giving the text another meaning, turning to parody.

When Count Gloucester's son in the tragedy of Shakespeare "King Lear" talks to Edgardo about old Lear and uses the expression "And that's true", this expression in P. Ackroyd's novel, in the speech of the hero turns into a paraphrase, acquires an intertextual text and at the same time is a reproduction of the old fathers who leave this life with a feeling of sorrow: "Mr. Lamb died as a result of its advanced senility few months after the murder of his wife. His last words, musitadas the ear of Charles, were: "And that is true" (2).

In another place in the work P. Ackroyd creates an intertextual correlation with Shakespeare's play to try to reveal the inner worlds of heroes

"Honey, I've found it. It was hidden in A good end. Charles Lamb entered the room with a thin green book in his hand. Mary turned smiling. He did not resist the enthusiasm of his brother, who allowed him to stop thinking about the perforated moon.

- What is it?

- Honey, what do you mean?

- How Well That Ends Bad Beginning? (2).

The allusion made from Shakespeare's "All's Well that Ends Well" shows itself in the dialogue between Charles and Mary and by addressing the new quotation, at the same time creating a new text.

The staging of fire in Island's house in P. Ackroyd's novel "The Great Fire of London" points to the burning of the library in the last stage of the novel "The Name of the Rose" by Umberto Eco; but finding Shakespeare's testaments is an allusion to another work of P.Ackroyd, called "The Last Testament of Oscar Wilde". The fact that the writer creates the intertextual correlation between specimens of English and world literature, his other works, and quotations cited from other works turns the novel towards the flow of information and increases its intellectual "load".

Allusions, quotations and reminiscence objects formulating the intertextual correlation must be recognized apart from the added text in itself and must possess independent information as a bearer of meaning. The main feature 
of P. Ackroyd's novel "The Lambs of London" is linked just with this situation - creation of a text among the other texts on the basis of a mutual theme, its correlation with the mutual theme, and its turning to an intertextual text in the condition of transition.

In his novel, along with creating intertextual correlations that have loaded the known text with new ideas, P. Ackroyd skillfully takes advantage of them to give direction to the events taking place in the novel. Throughout the novel, the reader can recognize the notable works created in the history of literature, and see how the ideas, touched upon in these works and their contents, find their reflections in P.Ackroyd's novels.

The fact that Shakespeare's creative activity was once subjected to arguments in literary studies, and the question whether he possessed the legal rights to authorship or not, all these problems were the contextual problematic of the work. Bringing up the right to authorship and mutual use, the novel is built upon true or false Shakespeare texts, while at the same time P. Ackroyd's hint to "Anti-Stratfordians" has taken use of "Shakespeare problem".

\section{The Dialogue between Past and Present}

The novel "The house of Doctor Dee" is valued as the most successful result of P. Ackroyd's postmodernist novel. The writer put forward a new postmodernist novel using the mixture of genres, uniting historical, gothic and detective novels namely in this novel. The writer using detective and drawing the reader into the intellectual play vivifies two plot lines and two historical events of different times. The first tells McJohn Dee's life story, the famous alchemist scientist of the XVI the century dealing with the past of Britain. The second deals with the narration of events of the second part of the XX century. The text novel is presented in turn at the same time but it vivifies the events of the different times and both of the plot lines are the first person narrators that's complicate secret "curtain" formed in the novel.

The epoch of Middle Ages comes to life in the character of John Dee, mystic scientific specialist. One of the peculiarities of this character is that the writer created him based on facts.

At the same time, P. Ackroyd added some features to the character Dee using his own rich fantasy. Doctor Dee, a confidential spy of Elizabeth I, was Mary Tudor's palace astrologer in youth and put forward the idea that humanity can possess divine power. Emphasizing this historical fact in the novel, P. Ackroyd puts on the novel a realistic mask and simultaneously creates the dialogue with the past.

With the help of intertextual dialogue, the writer forms the real background of the events described. For this, he appeals to archive documents and texts, uses John Dee's mathematical and medical heritage. Diary notes showing his meetings with ghosts and the works based on alchemist biography present it as a biographical novel reflecting Middle Ages reality. However, basing on historical facts makes it to resemble a historical novel.

With the help of intertextual dialogue the writer clarifies the events and on the background of the events, he manages to describe John Dee's characteristic features.

Despite numerating of the events happened nowadays at the beginning of the chapter, the chapters dealing with the past such as "The Hospital", "The Library", "The Abbey" help readers. Although it shows the aid to understand the text, in reality, drawing the reader into the game atmosphere makes the event more complicated. It must be noted that postmodernist play principle is used in the lower and higher levels of the novel "The House of Doctor Dee" and helps the intellectual play of the author with the reader.

The modern plotline of the novel deals with 29 aged Matthew Palmer's investigating the home's history that was inherited him by his father in Clerkenwell, London. After a strict research, Matthew Palmer learns that the house belongs to famous Doctor John Dee lived in the Middle Ages. In the parallel narrative line, it comes true that Doctor Dee takes great interest in mystical science and tries to prove that human may possess extraordinary power. Doctor Dee determines two-sided hero's destiny and the plot of the work. The events dealing with searching mystical giants in London and finding out the practice of bringing up "little man" (homunculus in Latin) stroll about past and modern time, spiritual séances are as believable as reality, but real events are hidden under "mystical" curtain. Doctor Dee makes contact from Middle Ages with modern times but his assistant Edward Kelley is shown as his medium. It must be noted that Edward Kelley is the historical person lived at the same time with John Dee. His name was called for several times in historical writings. He was as popular chemist of his time as John Dee. As he was verified as a false chemist in the English folklore, he was described as an envious person who betrays Doctor Dee and burns his house together with all manuscripts in P. Ackroyd's novel. This fire scene is the retrospection of P. Ackroyd's other work "The Great Fire of London" but for Dee it was the real moment, realizing to understand, the answer to the question "what's life?" The novel's narration in two-time dimensions ends mystically. The city of Atlanta embodiments London itself, but homunculus created by Din personifies Matthew Palmer. 
The novel "The house of Doctor Dee" is formed upon the allusion with the major works about Faustus and the hero of the novel is created typologically in the literary discourse dealing with Faustus in German folk-legend "Historia von D. JohannFausten", Christopher Marlowe's "The Tragical History of the Life and Death of Doctor Faustus", Johann Wolfgangvon Goethe's "Faustus". Being a historical person John Dee's life and creative activity was near to Faustus and Peter Ackroyd namely emphasizing this peculiarity managed to create a dialogue with existing texts using allusion and reminiscences. The dialogue with the interlocutor who claims that Doctor Dee made a contract with evil forces and achieved all he wants by magic:

"Foul and slanderous words," I said, "which should never have been spoken of me." He merely laughed at this, and my anger grew higher. "Shall the folly of idiots, and the malice of the scornful, become the new gospelamongall of you here? Shall I berobbed of my honest name and fame by those so far beneath me that I can scarcely see them?" "They are to be seen." "Heard, but not seen. You eagerly listen to the reports, and so I a minhugger-mugger condemned as a companion of the hellhound and a caller of damned spirits." ... "All my life," I continued more quietly, "I have spent in learning. If I seem to you another Faustus, why, sobe it" (3).

As its seen P. Ackroyd makes the dialogue with the text known to the reader and draws him into the game atmosphere. As we know this is the most useful writing style in postmodernist novels. The intelligible texts being described as known and unknown make the intertextual game between reader and text. The reader gets aware of the theme of Faustus. While getting ready to the intellectual atmosphere, the author presents a new Faustus - differs Doctor Dee from Faustus. Despite Faustus, Doctor Dee does not make a contract with Demon for getting divine knowledge but at the same time associates with creatures of "the other world" in his magic practice.

The hero of German folk legend Faustus calls Demon coming to the forest near Wittenberg in order to learn the secret of the earth and sky. The scene "reminding" this episode is changed in P. Ackroyd's novel and creates intertextual game with the help of allusion and reminiscence:

"He went on to tell me that the famous conjurer, Dr Faustus, lived in Witterburg about the year 1500; at my earnest entreaty, he very readily agreed to show me the house in which he had dwelt...Yet it was a poorerrand, since the old house of Faustus was no more than a fustytenementwithnorelics of his art. Hegelius, observing my down castlooks, then asked me if I would like to enter a wood adjoining the town, where it was said that Dr Faustus practiced his magic art and where he died — or was rather fetched by the Devil as the sum of all his labours" (3).

Never the less in German folk legend the soul of Faustus who parts from the God but contracts with demon is sent to the hell, or the same fate excepts the hero of "The Tragical History of the Life and Death of Doctor Faustus" by Ch. Marlowe but Goethe's Faustus' soul was justified after getting the higher level - to serve for people's happiness. P. Ackroyd changing the ending of known texts dealing with Faustus burns with the idea if searching London that became the part of Atlántida formulating the history in the face of Doctor Dee. The life of Doctor Dee is closed with the search of a mysterious city and at the end, it was found not in the other world but in this world, in the attempt of establishing "the garden of scientists - philosophers", the utopia of paradise.

The scene of libraries being burned by Edward Kelly, Doctor Dee's close brother-in-arms is the allusion to the final part of "The Tragical History of the life and Death of Doctor Faustus" by Ch. Marlowe, intertextual dialogue of works written in the Middle Ages:

"My God, my god, look not sofierce on me!

Adders and serpents, letmebreathe a while!

Uglyhell, gape not! come not, Lucifer!

I'llburnmybooks!-Ah, Mephistophilis!

[Exeunt Devils with Faustus.]

Chorus: Cut isthebranchthatmighthavegrownfullstraight,

And burnedisApollo'slaurel-bough,

That sometime grew within this learned man" (14).

Marlowe's hero refuses his books in order to get rid of death but P. Ackroyd's hero Dee becomes the observer to the fire made by Kelly, is indifferent to his library been laid in ashes and comes to the conclusion that material world is empty and meaningless. 
As it is seen P. Ackroyd managed to create a new plot with the help of secret and obvious allusions using known texts of Faustus.

The novel of "The house of Doctor Dee" by P. Ackroyd is based on the dialogue with the past. We can observe this dialogue in the whole work. The reader witnesses polemic with the ancient genius, great philosopher Aristotle in the main hero Doctor Dee's monologue explaining human and his place and mission in the world: "Aristotle himself tells us, "Nullaest magna scientiaabsquemixturadementiae", which is as much as to say, "There is no excellent knowledge without mixture of madness". But I deny even Aristotle in this, since he who has learning holds the flower of the sun, the perfect ruby, the elixir, the magisterium. It is the true stone, the home of the glorified spirit, the virtue of the soul of the world" (3).

At the same place, the hero shows his attitude to the thoughts of human by Giavanna Picodella Mirandola the permanent figure of the Italian Renaissance and Hermes Trismegistus uniting the divine force of Thoth, God of maturity of the ancient Egypt and Hermes, god of ancient Greece. The hero makes the dialogue with the past speaking of human magnificence and his ties with divine beginning:

"Yet I am not so foolish as to ignore the teaching of the great masters, Pico Della Mirandola and Hermes Trismegistus among them, when they assert the following: that to be myself is to be the world, to look into myself is to look into the world, to know myself is to know the world. The human form is more powerful than the sun because it contains the sun, more beautiful than the heavens because it contains the heavens, and he who sees it truly is richer than any king, for he has the entire art and understanding of the earth" (3).

As it is seen the novel of "The house of Doctor Dee" by P. Ackroyd is the postmodernist text example cleaning the borders of the elite and public literature, obviously based on intertextual dialogue, generally dealing with the "other text", quotation and allusions and reminiscences. It firstly deals with the fact that intertexts that are important for P. Ackroyd come from history, culture, and literature of the past.

\section{Intertextual Dialogue as an Ethical Problem}

P. Ackroyd's novel "The Casebook of Victor Frankenstein", a reminiscence of XIX century English writer Mary Shelly's novel "Frankenstein, or, The Modern Prometheus", is also an intertextual dialogue with the work of literature; for P. Ackroyd this work plays the role of pre-text, a rich architectural ground. By using gustation, reminiscence, and allusions which are the specific features of the postmodernist novel, and by getting into dialogue with the works written in the Victorian period using the principles of fragmentation and mosaic, the writer makes its new modification. For P.Ackroyd Mary Shelly's novel is a pretext, while a modern person's place in life and his attitude to the world and society in his vision of the world is described.

The leading feature of English postmodernist novels was the mutual correlation of these novels with previous literary systems, especially making use of the creative activities of the artists residing in the Victorian period. P. Ackroyd evinced his creative attitude to the existing ideas and forms their new modifications and new ideas and contents. The writer describes the plot of the writer Mary Shelly's novel "Frankenstein, or, The Modern Prometheus" in a new interpretation, sounding the narrative in the tongue of Frankenstein.

The scientist, being a graduate of Oxford University, succeeds in vivifying the dead, who were killed by the new achievement of science - by electric apparatus. But the terrifying creature invented by the scientist, possessing superhuman power, takes his revenge by killing the closest relatives of Frankenstein. Despite the fact that this pilot establishes similarity with Mary Shelly's novel, P. Ackroyd's novel ends with an unexpected final. It becomes clear that this terrifying creature exists only in the scientist's consciousness, and all the murders were realized by the scientist himself.

In this postmodernist novel of P. Ackroyd, it is possible to observe the reminiscences of novels such as Robert Louis Stevenson's "Strange Case of Dr. Jekyll and Mr. Hyde" (1886), Robert Albert Bloch's "Psycho" (1959), Chuck Palahniuk's "Fight Club" (1996), and Jame Graham Ballard's "Cocaine Nights" (1996). In these works, the hero puts the quilts of crimes in the names of other peoples, but finally, it becomes clear, that the events have taken place only in his imagination. In P. Ackroyd's novels too, the motif of duplication of the personality exists, but the events are realized only in the imagination of the hero.

The novel called "The Casebook of Victor Frankenstein is the "rewriting" of the biography of Percy Bysshe Shelley; it is a "new" take on the life of the romantic writer, written as his reminiscence. P. Ackroyd has not directly copied the biography of the poet, but by interpreting it he has written a "new" biography (we may say that this stylistic device, this method takes place in all the novels of the writer). The stage of the meeting of Frankenstein with P. Shelley at the Oxford University is really a historical fact. Though the first unsuccessful attempt of the writer's marriage occupies a certain place in the narrative, P.Ackroyd describes the suicide of the 
poet's wife as it was in reality but he describes it as the suicide of a woman not able to bear the separation and grief of her husband.

In addition, the writer includes the great poet of romanticism George Gordon Noel Byron into the text, and in order to make the novel more convincing, brings self-belonging to him in a clarity to the attitudes among Byron, P. B. Shelley, and M. Shelley. He makes additions to the creative talks between Byron and P.B.Shelley, brings quotations from the poem "Prometheus Unbound": Then he began to quote from one of his own poems, declaiming the words out of the carriage window as we passed through one Dutch Hamlet:

"I saw not, heard not, moved not, only felt

His presence flow and mingle through my blood

Till it became his life, and his grew mine,

And I was thus absorbed, until it passed" (1).

One of the writing styles of the Postmodernist novel is a limpid line between invention and reality, the loss of a border between reality and imagination, creating ample facilities for the writer's narrative. In P. Ackroyd's novels, creative interpretation sounds as reality. The allusions brought to P. B. Shelley's life are cemented with quotations cited from the works of the writer, giving a "new life" to the text.

P. Ackroyd, by taking advantage of the play principles of postmodernism, using the quotations cited from the poem "Prometheus Unbound" written by P. B. Shelley, created a self-belonging correlation with the novel "Frankenstein, or, modern Prometheus" written by Mary Shelley. The writer correlates the character of Prometheus with the chief hero of the novel Frankenstein, creating an image as if he too was opposed against the Creator. It is necessary to mention that the postmodernist novel is created on the borderline between mass literature and elite literature, and though P. Ackroyd's novel "The Casebook of Victor Frankenstein" is the reminiscence of the character of P. B. Shelley and his creative activity in the surface structure, in the deep structure it acts as the interpreter of the poet's philosophical views. The character of Frankenstein is the bitter consequence of the interpretation of the myth of Prometheus and the realization of dreams by the man of science himself.

P. Ackroyd's novel, besides the reminiscences made to the lives and creative activities of P. B. Shelley, G. G. Byron, M. Shelley, represents dialogues with other representatives of romanticism such as W. Wordsworth, R. Southey, J. Keats, and T. S. Coleridge in coordination with their poetic world. By the help of quotations, allusions, and paraphrases the writer makes a retrospection of the history and succeeds in "vivifying" the past with new interpretations. In P. Ackroyd's novel, there are allusions made from John Milton's poem "Paradise Lost", Dante Alighieri's works, and hints from Byron's poem "The Prisoner of Chillon", and Walter Scott's work "Marmion".

The quotation cited from Samuel Taylor Coleridge's IX sonnet gives a new meaning to the text and the writer; in order to express his thought, changes the literary discourse: "Where else may I rest my head? I ama pale roamer through the night, but in the night and darkness, I will remain" (1). S. T. Coleridge shared one and the same literary school with Percy Bysshe Shelley and Mary Shelley and was one of the artists who created the idea-aesthetic fusions of romanticism. His sonnets played a great role in the revelation of the inner world of his romantic heroes, turned to the symbol of the discrepancy between himself and his time. Like all the romantic poets S.T.Coleridge does not agree with the social life of his times, amd uses his innovative thoughts to cope with contradictions in life: "Pale roamer through the night! Thou poor forlorn!" (8).

Society does not accept the huge creature created by P. Ackroyd at the beginning of the work, then in spite of the fact that he kills all the close relatives of the scientists to take his revenge, at the end of the work he entreats him, and wishes his own death. The writer, by the cited quotation from the sonnets of S. T. Coleridge, who was the herald of romanticism, gives new meaning to the text, succeeding in the creation of the intertextual dialogue between the modern texts and the texts of the XIX century, at the same time describing a critical position on the "ugly creatures", unaccepted by the society. By using the principles of play of postmodernism, P. Ackroyd invites the reader to an intellectual play, by the help of another means of postmodernism, fragmentation, from the usage of already known texts, creates a new novel.

P. Ackroyd's address to the creativity of Shakespeare shows itself in many of his novels, and the novel "The Casebook of Victor Frankenstein" is not an exception. See the expression of Gertrude about Ophelia in act IV sceneVII of the tragedy "Hamlet" by Shakespeare:

"That shows his hoar leaves in the glassy stream.... 


\section{Till that her garments, heavy with their drink,}

\section{Pull'd the poor wretch from her melodious lay}

To muddy death". (18; 710)

The fact that P. Ackroyd "intrudes" the dialogue between Mary and Frankenstein into the text is an intertextual play, created by P.Ackroyd and which can be considered as a specimen of postmodernist style. We read in the novel: "I know it is wrong of me," she said eventually,

"but I cannot help thinking of Ophelia. There is a willow grows aslant a brook. You know it, Mr. Frankenstein?"

"Please call me Victor."

"We have gone beyond ceremony, I think. You shall call me Mary."

"Ophelia drowned herself, did she not?"

"Her garments, heavy with their drink, pulled the poor wretch from her melodious lay to muddy death. Those are the words of the queen. Not mine." (1)

The writer, taking advantage of Shakespeare's known to us tragedy, changes the discourse of the text and loads the text with new meaning creating an intertextual dialogue; at another point in the novel the expression which Frankenstein used in his talk with the servant is an intertextual correlation with Shakespeare's tragedy "King Lear" and is its reminiscence:

"You are entertaining our guest, Fred. What were you discussing?"

"Nothing, sir."

"Nothing can come of nothing."

"Sir?"

"Speak your mind."

"He says he is concerned for you". (1)

It is clear that King Lear in his meeting with his daughters wants to know their attitudes towards himself and his beloved daughter's answer upsets him:

"Cordelia: Nothing, my lord.

King Lear: Nothing!

Cordelia: Nothing.

King Lear: Nothing will come of nothing: speak again.

Cordelia: Unhappy that I am, I cannot heave

My heart into my mouth: I love your majesty

According to my bond; nor more nor less.

King Lear: How, how, Cordelia! mend your speech a little,

Lest it may mar your fortunes". (18; 911)

The play on the word as "Nothing will come of nothing" in the postmodernist novel changes the discourse and is "loaded" with new meanings. The fact that the servant protects him with all might from the interrogations of the guest visiting his house, on the contrary, creates new suspicions, and turns into "Nothing will come of nothing”.

As it is seen, by creating intertextual dialogues with the works of the above-enumerated authors of English literature, P. Ackroyd searches for answers to the moral and philosophical problems of his time. By determining the human being and his deeds in life, the human being and his/her place in life, by explaining the confrontation met by a creative person, in revealing the tragedies of creative lonely persons such as P.B.Shelley, Byron, and Victor Frankenstein, P.Ackroyd brings clarity to the idea stratum of the novel. The writer, with the help of reminiscences, allusions, quotations, and paraphrases, by creating dialogues with the texts established in the past centuries, has succeeded in describing the problems of modern man. 


\section{Conclusion}

One of the distinguishing features of the British postmodernist novel is making dialogues with the heritage and cultural epochs of the past centuries. The postmodernist novel in new Britain overturns to archetype in its past and any work dealing with this theme comes out the whole of classical value. From this point of view the analyzed works such as "The house of Doctor Dee", "The Lambs of London", "The Casebook of Victor Frankenstein" by Peter Ackroyd, the British writer was written on the plane of intertextual dialogue with literary texts of the past years. The writer brings to life the fragments of known narrative texts which are invisible, out of account by reader realize it by the means of literary reminiscence, allusion, quotation and historical retrospection.

Intertextual dialogue shows itself as a secret and obvious quotation, allusion, basing on historical and literary facts, in the form of imitation of the writing style of well-known writers in P. Ackroyd's novels. Reminiscences are used not only in creating the character of a hero but also degradation of known character. The use of intertextual dialogues, P. Ackroyd's novel philosophy is the writing style of postmodernist novels. It helps the writer to interpret the novel saving the literary narration, to create a new narration and to draw a reader into a new intellectual game atmosphere.

\section{References}

Ackroyd, P. (1993). The House of Doctor Dee Retrieved from http://royallib.com/read/Ackroyd_Peter/The_house_of_Doctor_Dee.html\#122942

Ackroyd, P. (2006). The Lambs of London. Retrieved from https://readonlinefree4.net/book-reader/the-lambs-of-london

Ackroyd, P. (2008). The Casebook of Victor Frankenstein. Retrieved from http://royallib.com/read/Ackroyd_Peter/The_Casebook_of_Victor_Frankenstein.html\#0

Allen, A. (2000). The Anti-Subjective Hypothesis: Michel Foucault and the Death of the Subject. The Philosophical Forum, 31(2), 113-130. https://doi.org/10.1111/0031-806X.00031

Bakhtin, M. (1981). The Dialogic Imagination. Edited by Michael Holquist. Translated by C. Emerson \& M. Holquist. University of Texas Press. Austin and London. Retrieved from http://www.public.iastate.edu/ carlos/607/readings/bakhtin.pdf

Barthes, R. (1977). Image Music Text. Essays selected and translated by Stephen Heath. Fontana: Fontana Press. Retrieved from https://rosswolfe.files.wordpress.com/2015/04/roland-barthes-image-music-text.pdf

Baudrillard, J. (2007). Retrieved from https://plato.stanford.edu/entries/baudrillard/

Coleridge, S. T. $\quad$ (n. $\quad$ d.) The Outcast. Retrieved from https://genius.com/Samuel-taylor-coleridge-the-outcast-annotated

Finney, B. (1992). Peter Ackroyd, Postmodernist Play and Chatterton. https://doi.org/10.2307/441621

Gibson, J., \& Wolfreys, J. (2000). Peter Ackroyd: The Ludic and Labyrinthine Text. London, UK: Palgrave Macmillan. https://doi.org/10.1057/9780230288348

Heartfield, J. (2002). Postmodernism and the "Death of the Subject". Retrived from https://www.marxists.org/reference/subject/philosophy/works/en/heartfield-james.htm

Hnninen, U. (1997). Rewriting literary history: Peter Ackroyd and Intertextuality. Retrieved from http://ethesis.helsinki.fi/julkaisut/hum/engla/pg/hanninen/rewritin.pdf

Kristeva, J. (1986). Word, Dialogue and Novel. Retrieved from https://archive.org/stream/TheKristevaReader/The\%20Kristeva\%20Reader_djvu.txt

Quliyev, Q. (2012). XX əsr ədəbiyyatşünaslıq konsepsiyaları. Bakı.

Marlowe, C. (2009). The Tragical History of Doctor Faustus. Retrieved from http://www.gutenberg.org/files/779/779-h/779-h.htm

Onega, S. (1995). Metafiction and Myth in the novels of Peter Ackroyd. Columbia, USA: Camden House.

Vechinski, M. J. (2016). Christine Brooke-Rose and the Science of Fiction: Rethinking Conceptual Writing and Artificial Intelligence in Xorandor. https://doi.org/10.1080/00111619.2015.1091288

Wells, S., \& Taylor, G. (2005). The Oxford Shakespeare the Complete Works (2nd ed.). Oxford: Clarendon Press. 


\section{Copyrights}

Copyright for this article is retained by the author(s), with first publication rights granted to the journal.

This is an open-access article distributed under the terms and conditions of the Creative Commons Attribution license (http://creativecommons.org/licenses/by/4.0/). 